\title{
Neonatal Injury Related to Birth
}

National Cancer Institute

\section{Source}

National Cancer Institute. Neonatal Injury Related to Birth. NCI Thesaurus. Code C101035.

An injury sustained to a neonate during the birthing process. 